\title{
Determination of ecologically admissible volumes of take-off of water from small rivers
}

\author{
Yatsyk A. ${ }^{1}$, Pasheniuk I. ${ }^{2}$, Hopchak I. ${ }^{3}$, Ba-siuk T. ${ }^{4}$ \\ 1, ${ }^{2}$ Ukrainian research institute of water management and ecological problems, Inzhenernyi lane, 4 B, Kyiv, \\ 01010, Ukraine, ${ }^{3}$ National university of water and environmental engineering, Soborna Str., 11, Rivne, 33028, \\ Ukraine, ${ }^{4}$ International university of economics and humanities, Academician Stepan Demianchuk Str., 4, Rivne, \\ 33000, Ukraine; e-mail:1, ${ }^{2}$ undiwep@gmail.com, ${ }^{3}$ gopchak_igor@ukr.net, ${ }^{4}$ tanya_basyuk@ukr.net
}

The purpose. To determine ecologically admissible volumes of take-off of water from small rivers. Methods. Research is lead according to regular supervision over small rivers of Prypiat Polissia of Ukraine. At assessment of ecologically admissible volumes of take-off of water from the rivers the basic condition is preservation of ecologically safe condition of water eco-system at which changes of its structurally-functional organization do not harm to ability of natural complexes to self-control, to autopurification and selfrestoration. Results. Ecologically admissible volume is determined of take-off of water that enables to carry out take-off of water from rivers for various economic needs without damage of water eco-system. It is established that under the influence of anthropogenic load water eco-systems for last years have undergone essential changes. In particular significant transformations of water-intaking area and big regulation of drain are observed. Ecologically admissible volumes are determined of water take-off from rivers for the long-term period in years with different security $(50,75,95 \%)$, and assessment of ecologically admissible volume of take-off of drain under condition of preservation river eco-system is carried out. Calculations have shown that in very shallow year ( $\mathrm{P}=95 \%)$ water resources do not provide volumes of ecological drain, and in shallow year $(\mathrm{P}=75 \%)$ its water resources slightly exceed ecological drain. The volume of ecological drain almost at half of researched rivers reaches $40 \%$, and in others $-50-60 \%$ of norm of drain. Conclusions. It is established that in Prypiat Polissia of Ukraine in very shallow years for water-economic needs is necessary to use stocks of other water resources. The further calculations of ecologically admissible minimal volumes of water should be complex and consider as much as possible criteria of condition of river that will enable to reveal such criteria which worst of all influence its condition.

Key words: river, water take-off, water content of river, volume of water, anthropogenic load, auto-purification.

DOI: https://doi.org/10.31073/agrovisnyk201903-09

Introduction (problem). In recent decades, more and more attention has been paid to the study of the problems of small rivers. This is primarily due to the awareness of the importance of small water bodies in the functioning of medium and large rivers. Modern anthropogenic impact on aquatic ecosystems has led to a number of negative impacts and significant changes in most water bodies in Ukraine. In the conditions of nonstandardized water selection and stocking of the ecosystem runoff, a number of rivers, especially small ones, actually operate in medium-wind conditions, and in the spring, in extremely shallow waters. This led to a decrease in river flows, their self-cleaning ability, deterioration of water quality, and so on. Most flood plains, which primarily act as a barrier to polluted runoff from the catchment, are drained and are in complete degradation. All this leads to an aggravation of the ecological situation of the river ecosystems [1-5]. Therefore, there is a need to introduce restrictions on the selection of surface runoff, even on those rivers where they did not exceed the ecologically acceptable. Since the absence of ecological standards for the determination of ecologically acceptable water volumes in rivers creates difficulties in project, water management and water protection practices. The degree and nature of the regulation of river runoff and the normalization of the ecologically permissible withdrawal must be mutually agreed [6].

Analysis of recent research and publications of the subject. Today there is no single environmental standard for determining ecologically acceptable minimum water volumes on the rivers of Ukraine. Much of the publications are based mainly on particular aspects of the problem. Researchers in the direction of determining the environmental costs of water in the rivers were engaged in many scientists. In particular, S. Vendrov, A. 
Chernyayev (Russia), P. Gatylo, I. Filippovich, F. Kefali, B. Faschevsky (Belarus), M. Lalin (Moldova), A. Kask, T. Mallint (Estonia). In Ukraine, J. Grib, O. Obodovsky, A. Yatsyk, V. Moklyak, V. Kholodenko and others made a significant contribution to the definition of environmental water consumption. [6, 7].

The purpose of the research - is to determine the ecologically acceptable volumes of water selection from small rivers.

The object of research The rivers are selected within the territory of the Pripyat Polissya of Ukraine, namely: Pripyat, Vyzhevka, Turia, Stohid, Vyrka, Sluch, Tnya, Smolka, Ubort, Uzh.

Materials and methods. Preservation of the sustainable functioning of the river ecosystem for the increasing level of anthropogenic intervention depends on the search and establishment of limiting factors that determine the limitation of such intervention. In assessing the ecologically acceptable volumes of water from the rivers should take into account the main condition - the preservation of the ecologically safe state of the aquatic ecosystem, in which changes in the structural and functional organization of the ecosystem do not undermine the ability of natural complexes to self-regulation, self-purification and self-healing. The study was conducted in accordance with the Methodology [8].

Research results. Aquatic ecosystems under the influence of anthropogenic loading have undergone significant changes in recent years. In particular, there are significant changes in the water catchment area, a large stocking of runoff. High rates of development of water resources and their irreversible costs have violated the conditions for the formation of water regime of rivers, and the constant flow of sewage has reduced their ability to self-purification. Exhaustion and pollution of rivers can disrupt the natural processes of their reproduction, lead to complete degradation of water bodies and prevent any use of them [1, 2, 4, 9].

First of all, the ecologically acceptable volume of water selection was determined, which allows to collect water from the rivers for various economic needs, without prejudice to the aquatic ecosystem. It is worth noting that the standards of ecologically permissible non-returning surface runoff are established in the form of constant values in different seasons of the year for years with different water content and should not lead to changes in the characteristics of the water body and significantly beyond the limits of natural seasonal long-term fluctuations. The obtained results reflect the state of provision of the ecologically permissible minimum runoff (We) in the rivers of Polissya by water resources in different years $(50 \%, 75 \%, 95 \%)$.

It is established that in a very shallow water year $(P=95 \%)$, water resources do not provide the volume of ecological drainage, and in the shallow water year $(P=75 \%)$ its water resources exaggerate the ecological discharges for the most part to a small extent. The volume of ecological drainage in almost half of the studied rivers reaches $40 \%$ of the norm of runoff, and in other rivers $-50-60 \%$ of the runoff, with the exception of the river Vorky near the village. Animal, where environmental runoff is $74.4 \%$ of the norm.

In particular, the results of the study showed that under the conditions of preservation of the functioning of river ecosystems, the allowable volume of river runoff of studied hydrocarbons is within the range of $25-48 \%$, except for the Stokhid, Tnia, Smolka, and Ubort rivers in which the limit reaches 50-65\%. It should be noted that this value consists not only of volumes of irreversible water consumption. It also concentrates all the costs of river runoff due to economic activity. And for the Stokhid, Tnia, and Ubort rivers there are significant watersupply reserves due to channel flow regulation. Also, ecologically acceptable volumes of water selection from rivers for a long-term period in years of different security were determined (Table 1).

It was established that the greatest demand for water resources in a very shallow year is observed on the rivers Pripyat, Sluch, Uberte $(177.2 \%, 87.1 \%, 53.8 \%, 70.3 \%$ respectively), and the smallest in the rivers Turia, Stokhid, Virka $(7.3 \%, 2.7 \%, 6.9 \%)$. Consequently, we can conclude that for the rivers of the Pripyat Polissya of Ukraine during very shallow years, it is necessary to search for water resources for water management needs or not to use the rivers during these periods in general.

It is worth noting that the water objects under investigation occur in the Polissya area of Ukraine, which is characterized by: sufficient and excessive humidification of the river basin, the maximum provision of river runoff during the flood, and a greater minimum runoff in the summer and autumn of the rivers. In particular, the ecologically acceptable volumes of sampling from the rivers are somewhat overestimated due to the waterloggedness in the upper reaches of the rivers, where the runoff is in a natural state. 
Table 1. Ecologically acceptable selection volume of water from rivers for a long period of time

\begin{tabular}{|c|c|c|c|c|c|}
\hline \multirow[t]{2}{*}{ River } & \multirow[t]{2}{*}{$\begin{array}{l}\text { Hydrological } \\
\text { point }\end{array}$} & \multicolumn{2}{|c|}{$\begin{array}{l}\text { Ecologically acceptable } \\
\text { volume of water selection, } \\
\text { million } \mathrm{m}^{3}\end{array}$} & \multirow{2}{*}{$\begin{array}{c}\text { Allowable for } \\
\text { selection from the } \\
\text { river, } \\
\% \text { from the norm of } \\
\text { runoff }\end{array}$} & \multirow{2}{*}{$\begin{array}{l}\text { The need for water } \\
\text { resources in a very } \\
\text { shallow year, } \\
\text { million } \mathrm{m}^{3}\end{array}$} \\
\hline & & $\mathrm{W}_{850 \%} / \mathrm{W}_{875 \%}$ & $W_{e}$ & & \\
\hline \multirow{2}{*}{ Pripyat } & v. Richycya & $73,1 / 5,9$ & 185,5 & 28,3 & 87,1 \\
\hline & v. Lyubyaz & $91,8 / 6,7$ & 298 & 23,6 & 177,2 \\
\hline Vyzhevka & v. Stara Vyzhevka & $34,8 / 3,8$ & 48,2 & 41,9 & 20,2 \\
\hline \multirow{2}{*}{ Turia } & v. Yahidne & $22,7 / 4,7$ & 24,3 & 48,3 & 7,3 \\
\hline & t. Kovel & $53,2 / 5,2$ & 83,8 & 38,8 & 28,8 \\
\hline Stohid & v. Malynivka & $35,3 / 14,3$ & 22,7 & 60,9 & 2,7 \\
\hline Vyrka & v. Svaryni & $6,4 / 0,4$ & 18,6 & 25,6 & 6,9 \\
\hline Sluch & v. Gromada & $101,2 / 23,2$ & 165,8 & 37,9 & 53,8 \\
\hline Tnya & v. Bronyki & $74,3 / 15,3$ & 39,7 & 65,2 & 22,7 \\
\hline Smolka & v. Susly & $31,8 / 5,8$ & 31,2 & 50,5 & 12,2 \\
\hline \multirow[t]{2}{*}{ Ubort } & $\begin{array}{l}\text { v. Rudnya } \\
\text { Ivanivs'ka }\end{array}$ & $30,3 / 1,3$ & 28,7 & 51,4 & 18,7 \\
\hline & v. Perga & $227,6 / 46,6$ & 151,4 & 60,0 & 70,3 \\
\hline Uzh & t. Korosten' & $66,9 / 6,9$ & 73,1 & 47,8 & 35,1 \\
\hline
\end{tabular}

Analyzing the indicators of the collection of water from surface and underground sources for production, economic needs and fish farming, it is established that in river basins it does not exceed the allowable volume of river runoff, which is set for selection according to calculations. Therefore, based on the ecologically acceptable volume of irreversible water consumption within the water intake basin of the river, it is necessary to determine the environmental runoff to preserve the ability of the aquatic ecosystem to self-regulate, self-purify and selfrepair. The norms of the maximum allowable annual non-return of river runoff selection and environmental runoff shall be set differentiated for each water object in different hydrocarbons.

The results of the assessment of the ecologically acceptable volume of sewage selection provided that the river ecosystems are preserved are given in Table. 2

Table 2. Estimation of the ecologically acceptable volume runoff selection provided that river ecosystems are preserved (for example, the rivers of the Pripyat Polissya of Ukraine)

\begin{tabular}{|c|c|c|c|c|c|}
\hline \multirow{3}{*}{ River } & \multirow{3}{*}{$\begin{array}{l}\text { Hydrological } \\
\text { point }\end{array}$} & \multicolumn{4}{|c|}{ Volume of river runoff } \\
\hline & & \multirow{2}{*}{$\begin{array}{l}\text { Average long- } \\
\text { term value, } \\
\text { million } \mathrm{m}^{3}\end{array}$} & \multirow{2}{*}{$\begin{array}{l}\text { Ecologically acceptable } \\
\text { volume } \mathrm{W}_{\mathrm{e}} \\
\text { million } \mathrm{m}^{3}\end{array}$} & \multicolumn{2}{|c|}{$\begin{array}{c}\text { Allowable for selection from } \\
\text { the river }\end{array}$} \\
\hline & & & & million $\mathrm{m}^{3}$ & $\begin{array}{l}\% \text { from the norm } \\
\text { of runoff }\end{array}$ \\
\hline \multirow{2}{*}{ Pripyat } & v. Richycya & 258,6 & 185,5 & 73,1 & 28,3 \\
\hline & v. Lyubyaz & 389,8 & 298 & 91,8 & 23,6 \\
\hline Vyzhevka & v. Stara Vyzhevka & 83 & 48,2 & 34,8 & 41,9 \\
\hline \multirow{2}{*}{ Turia } & v. Yahidne & 47 & 24,3 & 22,7 & 48,3 \\
\hline & t. Kovel & 137 & 83,8 & 53,2 & 38,8 \\
\hline Stohid & v. Malynivka & 58 & 22,7 & 35,3 & 60,9 \\
\hline
\end{tabular}




\begin{tabular}{|l|l|c|c|c|c|}
\hline Vyrka & v. Svaryni & 25 & 18,6 & 6,4 & 25,6 \\
\hline Sluch & v. Gromada & 267 & 165,8 & 101,2 & 37,9 \\
\hline Tnya & v. Bronyki & 114 & 39,7 & 74,3 & 65,2 \\
\hline Smolka & v. Susly & 63 & 31,2 & 31,8 & 50,5 \\
\hline \multirow{3}{*}{ Ubort } & $\begin{array}{l}\text { v. Rudnya } \\
\text { Ivanivs'ka }\end{array}$ & 59 & 28,7 & 30,3 & 51,4 \\
\cline { 2 - 6 } & v. Perga & 379 & 151,4 & 227,6 & 60,0 \\
\hline Uzh & t. Korosten' & 140 & 73,1 & 66,9 & 47,8 \\
\hline
\end{tabular}

Note that seasonal and perennial unevenness of surface runoff [10], especially in the valleys of small rivers and middle rivers, limits the possibilities of rational, uninterrupted and environmentally safe use of water resources. A significant part of river runoff is forcibly discharged during the spring period. At the same time, in shorter periods, water shortages often occur, which create crises in the water supply of the population and sectors of the economy.

Given that the regime of surface waters is largely random, it is difficult to predict the time to reduce the size of the drain to the established limits. The need for the inclusion of groundwater intakes can be determined only by the data of operational observations of the drain in the closure. Therefore, taking into account the reduction in recent years, the number of monitoring stations under the regime and quality of natural waters, it is necessary first of all to take measures for the restoration of hydrological stations and the expansion of the volume of observations.

\section{Conclusions and perspectives of further searches in this direction}

Summarizing the above, it should be noted that calculations of ecologically permissible minimum water volumes should be comprehensive and take into account as many criteria as possible for the state of the river ecological-hydrological, water-forming, hydrobiological, hydrochemical, etc. This will first of all enable us to identify the criteria that have the worst effect on the state of the river.

\section{Bibliography}

1. Yatsyk A.V. (1997). Ekolohycheskye osnovy ratsyonalnoho vodopolzovanyia [Ecological basis of rational water use]. Kiev: Heneza. pp. 640. [In Russian].

2. Yatsyk A.V., Levycka S.O., Pashenyuk I. A. (2007) Antropogenne navantazhennya na vodni ekosystemy ta osnovni pryncypy ekologichnogo normuvannya [Anthropogenic pressure on aquatic ecosystems and basic principles of ecological regulation] Rivne: NUVHP, pp. 108-119 [in Ukrainian]

3. Yatsyk A.V., Gryshchenko Yu. M, Volkova L. A. Pashenyuk I. A (2007) Vodni resursy: vykorystannya, oxorona, vidtvorennya, upravlinnya: [Water resources: use, protection, reproduction, management]. Kyiv: Geneza. pp. 360. [in Ukrainian]

4. Hryb V., Klymenko M., Sondak V. (1999). Vidnovna hidroekolohiia porushenykh richkovykh ta ozernykh system (hidrokhimiia, hidrolohiia, upravlinnia) [Restorative hydroecology of disturbed river and lake systems (hydrochemistry, hydrology, management)]. Navch. posib. T. 1.-Rivne : Rivnen. derzh. tekhn. un-t. pp. 348. [in Ukrainian].

5. Yatsyk A., Pasheniuk I., Hopchak I., Basiuk T. (2017) Ocenka yspolzovanyya zemelnyx resursov v bassejnax malyx rek Polesya Ukrayny [Assessment of the use of land resources in the basins of small rivers Polesie of Ukraine] Voprosy nauk o Zemle v koncepcyy ustojchyvogo razvytyya Belarusy: sbornyk nauchnyx statej: v 2 ch. Ch.2, M-vo obrazovanyya Respublyky Belarus, Gomelskyj gos. un-t ym. F. Skoryny. Gomel: GGU ym. F. Skoryny, pp. 211-216 [In Russian]

6. Yatsyk A., Hopchak I., Nikityuk D., Basiuk T. (2017) Metodologiya vyznachennya ekologichno dopustymyx rivniv vidboru vody $z$ malyx richok [Methodology for determining the ecologically acceptable levels of water sampling from small rivers] Voda: problemy ta shlyaxy vyrishennya: zbirnyk statej Naukovo-praktychnoyi 
konferenciyi iz mizhnarodnoyu uchastyu, m. Rivne, Zhytomyr: Vyd-vo ECz «Ukrekobiokon», pp. 304-309 [in Ukrainian].

7. Holodenko V.S. (2012) Suchasni metodyky vstanovlennya ekologichno dopustymyx minimalnyx vytrat vody na richkax Prypyatskogo Polissya Ukrayiny [Modern methods of establishing ecologically permissible minimum water consumption on the rivers of the Pripyat Polissya of Ukraine] Geografiya ta turyzm. Vyp. 21. pp. 241-249. [in Ukrainian]

8. Yatsik A.V., Byshovec L.B., Kyrychenko S.M. (2002) Metodyka vyznachennya ekologichno dopustymyx rivniv vidboru vody $z$ richok $z$ metoyu zberezhennya stalogo funkcionuvannya yix ekosystem [Methodology for determination of ecologically acceptable levels of water selection from rivers in order to preserve the sustainable functioning of their ecosystems], Kyiv, pp. 48. [in Ukrainian]

9. Grebin V.V. (2004) Suchasni zminy stoku richok Prypyatskogo Polissya [Modern changes in the runoff of the Pripyat Polissya rivers] Gidrologiya, gidroximiya i gidro ekologiya. Kyiv: VGL «Obriyi». T. 6. pp. 74-85. [in Ukrainian]

10. Xublaryan M.G., Kovalevskyj V.S., Bolgov M.V., (2005) Koncepciya upravleniya vodno-resursnymy systemamy na osnove sovmestnogo yspolzovanyya poverxnostnyx y podzemnyx vod [The concept of managing water-resource systems based on the combined use of surface and groundwater] Vodnye resursy. $T$. 32, 5. pp. 617-624. [In Russian] 